\title{
European influences on Chinese humanitarian practices ${ }^{1}$
}

A longitudinal study

\begin{abstract}
$^{2}$
Mao Weizhun

Mots-clés : Action humanitaire, Chine, Europe, Histoire.

Dans cet essai, nous examinons l'impact de la culture européenne sur les pratiques d'action humanitaire chinoises. Nous commencons par rappeler une série d'éléments-clés de contexte, portant sur l'action bumanitaire en Chine et en Europe, puis nous décrivons les quatre étapes chronologiques de l'influence européenne sur les pratiques chinoises. En bout de course, nous considérons le rôle de l'instrument communautaire ECHO à cet égard.
\end{abstract}

Keywords: Humanitarian practices, China, Europe, History.

In this paper, we examine how European systems of thought and action have shaped humanitarian practices in China. After recalling a series of key background elements of European and Chinese humanitarianism, we describe the four historical steps of European influence on Chinese relief practices, and we finish by considering the current role of the European Community Humanitarian aid Office (ECHO) in this context.

\section{Key elements of European and Chinese humanita- rianism}

\subsection{Modern Humanitarianism and Its European Footprints}

To define humanitarianism and its related concepts like humanitarian action is a tricky task. However, a largely accepted definition put forward by the International

1 This research is supported by RENMIN University of China Graduate Science Foundation (Name: Research on International Humanitarianism in China, 1949-2009; No. 10XNG008). Mao Weizhun is PhD student at the School of International Studies, Renmin University.

2 We thank Stéphane Baele and Grégoire Lits for stylistic work on this paper. 
Committee of the Red Cross (ICRC) in the late 1980s, presents humanitarian actions as impartial, independent, and neutral provisions of relief to those in immediate need because of human-made and natural disasters. In short, the essence of humanitarian action is "to save lives at risk" 3". As a humanitarian organization, the ICRC put forward seven core principles of humanitarianism, i.e. humanity, impartiality, neutrality, independence, voluntary service, unity, and universality ${ }^{4}$.

This definition has been debated since the 1990s, mainly regarding two aspects. First, some scholars and practitioners asked to extend it to linkages of relief, reconstruction and development (LRRD). Second, some core principles were criticized following the rise of Médecins Sans Frontières (MSF). This NGO, whose practices are sometimes described as "more rebellious and rowdy humanitarianism" ${ }^{5}$ ", challenged the orthodox idea that politics should not interact with humanitarianism, and hence rejected the principle of neutrality.

However, the core idea that bumanity is the fundamental principle of humanitarian action and humanism its philosophical foundation, can't be removed. Humanity requires casting all the attention on people. According to Pictet, this principle means to "prevent and alleviate human suffering wherever it may be found", "to protect life and health and to ensure respect for the human being", and "to promote mutual understanding, friendship, cooperation and lasting peace amongst all peoples ${ }^{6}$." Humanism as a philosophy is argued to have a close relationship with cosmopolitanism as well ${ }^{7}$.

Europe is the root of modern culture and advanced technology; the continent initiated and dominated the modernization process until very recently. Moreover, Europe has traditionally been on top of the international political system (i.e. the Westphalian System), at least until the end of World War II, and has witnessed the origins of modern diplomacy among different sovereign states. À number of currently recognized rules were created by Europeans.

The current humanitarian system is also a product of western society, and Europe has played a significant role in its development ${ }^{8}$. This is not to say that humanitarian elements such as life saving and suffering relief are not embedded in diverse cultural traditions and different civilizations; however, modern humanitarianism (not only its phi-

\footnotetext{
${ }^{3}$ Barnett, Michabe and Thomas Weiss, "Humanitarianism: A Brief History of the Present", in Barnett, Michabe and Thomas Weiss eds. (2008), Humanitarianism in Question: Politics, Power, Ethics, Cornell University Press, p.11.

4 Pictet, Jean, (1979) The Fundamental Principles of the Red Cross: Commentary, Geneva: Henry Dunant Institute.

${ }^{5}$ Barnett, Michabe and Thomas Weiss, "Humanitarianism: A Brief History of the Present", p.37

6 Pictet, Jean, (1979) The Fundamental Principles of the Red Cross: Commentary.

${ }^{7}$ Barnett, Michabe and Thomas Weiss, "Humanitarianism: A Brief History of the Present", p.12

${ }^{8}$ Barnett, Michabe and Thomas Weiss, "Humanitarianism: A Brief History of the Present".
} 
losophical roots but also its organization) clearly dates back to Christian notions such as caritas, and to the Renaissance and the Enlightenment. Today, most of professional expertise in humanitarian actions is still labeled "Made in Europe". Just like Hugo Slim once mentioned, "the formal [humanitarian] system has adopted many of the routine practices of modern welfare provision in Western states?." In addition, most of the big relief agencies have their origins or headquarters in Europe, such as ICRC, Oxfam, MSF, Actionaid International, CARE, Catholic Relief Services, etc.

\subsection{China: A crucial territory for humanitarian aid}

China is one of the four countries whose culture may claim a 5000-years cultural history. Unfortunately, from the 18th century, China was gradually trapped into a stagnant situation, living on memories of the past "Celestial Empire" (Tianchao Daguo); at the same time, modern civilization and technology quickly developed in Europe. The Industrial Revolution in Europe faced an isolation policy in China. The empire gradually declined whereas Europe synchronously rose. After British warships and cannons destroyed China's isolation policy in the First Opium War in the 1840s, European culture was made available to China. During this process, European elements were slowly or quickly, completely or partly, successfully or failingly embedded into Chinese structures of thought and action, which triggered a series of cultural conflicts between China and Europe. The introduction of the European humanitarian approach, and the subsequent reform of Chinese related humanitarian traditions, are the byproducts of this westernization process.

As a frequently disaster-affected country, China has provided to various actors - included those from the European sphere - a great platform to launch diverse humanitarian practices. Chinese actors paid attention to western humanitarian aid, and adapted the Chinese traditional disaster response system critically.

\subsection{Traditional Disaster Response System in China}

China's own disaster response and relief traditions have a long history that takes his roots in multiple experiences and lessons from disasters. This specific kind of humanitarian tradition has both advantages and disadvantages; to apply a new and advanced humanitarian approach, though, seems to constitute a progress.

${ }^{9}$ Slim, Hugo, (2006) "Global Welfare: A Realistic Expectation for the International Humanitarian System?", ALNAP Review of Humanitarian Action in 2005. 
In Europe, to deliver relief for disaster victims is a basic governmental function. Ancient China also built its disaster and famine response systems that way. However, these two disaster responses systems eventually lead to different results.

The complexity of the Chinese system, characterized by heavily detailed laws, couldn't guarantee the effectiveness of relief delivery, especially during periods of dynasty shifting. For example, the Qing Dynasty had a comprehensive disaster relief system, including related bureaucratic structures and laws; but such complexity had very few positive effects. This theoretically perfect system has never been able to maintain an efficient relief delivery; moreover, it even caused human-made disasters, because of corruption and weak governmental capacities. In fact, the complete system was to complex to be implemented, and existed in name only. It is incredible but true that this system and its actors actually worsened the death toll of emergent disasters. As George Staunton once noted, the Chinese system provided a lower level of effectiveness to meet victims' needs compared with the European system, in spite of its perfection and comprehensive nature ${ }^{10}$. Somehow differently, Karl Wittfogel pointed out the advantages of the Chinese relief system - stronger central authority and administrative capacity, which can mobilize plentiful human capital and money in case of emergency - but noticed that once the central authority is weakened, all the advantages transform into serious disadvantages: prevailing corruption, bad information control and complicated bureaucratic procedures among others ${ }^{11}$.

A different system emerged in Europe, although its relevant laws also seemed to be rough, and although responsibilities depended on local governments and churches. England created its first relief-related law in 1601 : the Poor Law or 43 Elizabeth, which remained an influential relief law in Europe for a long time. This law and its amendments (1723 and 1834) legally guaranteed a relief, understood as a governmental function, and set up relevant governmental agencies within the system of social security. These laws defined governmental relief actions, and enabled a good resource allocation to disaster relief ${ }^{12}$; they soon became the model of western disaster response system.

${ }^{10}$ Staunton, George, (1998) An Authentic Account of an Embassy from the King of Great Britain to the Emperor of China, translated by Ye Duyi, Shanghai Book Shop Press.

11 Wittfogel, Karl, (1958) Oriental Despotism: A Comparative Study of Total Power, New Haven: Yale University Press.

$12 \mathrm{Bu}$, Fengxian, (2007) "Comparative Research on the Reason of Natural Disaster in Ancient China and European Countries", Ancient and Modern Agriculture, No. 3, 2007. 


\subsection{Sino-European Exchanges before the $20^{\text {th }}$ Century: A Background}

The first wave of religious contact between China and Europe took place around AD 635, during the Tang Dynasty (AD 618-907), when China was a trade and cultural center in the world ${ }^{13}$. However, there is no significant evidence indicating that a SinoEuropean dialogue was really conducted.

A more regular introduction of western culture and the emergence of a bilateral dialogue can be traced back to as early as before the Yuan Dynasty (AD 1279-1368), when Genghis Khan and his successors conquered a significant part of the Eurasian continent with their Mongolian troops. On the one hand, the Mongols brought elements of Chinese culture to Europe meanwhile they also forced a lot of European people to move to China, which unintentionally contributed to the cultural communication. In 1289, Catholic missionaries were officially allowed to preach in China ${ }^{14}$. On the other hand, Marco Polo introduced China and its cultures to European people. The Travels of Marco Polo (Il Milione), for instance, attracted European interest for China and promoted bilateral dialogue regarding culture and religion.

A third wave of Sino-European communication took place at the end of the Ming Dynasty (1368-1644) and the beginning of the Qing Dynasty (1644-1912). During this period, people like Michele Ruggieri and Matteo Ricci (to whom we'll turn later on) significantly activated the Sino-European dialogue. The latter was called the first "home universale 15 ", and recognized - thanks to a process of "inculturation" ${ }^{16 "}$ - as the pioneer of communication between China and western cultures ${ }^{17}$. After Ricci, Juan Adam Shall von Bell and Ferdinand Verbiest became famous figures during the Qing period. These three "fathers" of the Sino-European dialogue all built an excellent relationship with the Chinese ruling class and officials, and even with the Emperor Shunzhi and KangXi - which tends to indicate that they had some influence on national policy making. Moreover, it appears that the first humanitarian relief in China happened in 1604, with the participation of Matteo Ricci and other missionaries, although it did not correspond to modern conceptions of humanitarian action in a strict sense.

\footnotetext{
${ }^{13}$ Gu, Weimin, (2003) History of Catholicism in China, Shanghai: Shanghai Bookshop Press.

${ }^{14}$ Leung, Ka Lun, (1988) Catholic History of China, Hong Kong: Tien Dao Publishing House. Ltd.

15 Hirakawa, Sukehiro, (1999) Matteo Ricci, translated by Liu Anwei and Xu Yiping, Beijing: Guangming Ribao Publisher.

16 Pope John Paul II, (2011) Message of His Holiness Pope John Paul II for the Fourth Centenary of the Arrival in Beijing of the Great Missionary and Scientist Matteo Ricci, S.I., Vatican, 24 October 2001

${ }^{17}$ Fang, Hao, (2008) Communication History between China and West, Shanghai: Shanghai Renmin Press.
} 
After this period, a long-term "isolation policy" (Biguan Suoguo) and other political considerations barred Catholics from China during more than 100 years, from 1715 to 1845 and the first Opium War. The freedom of preach was then legally guaranteed by the series of Tianjin Treaties between China, Russia, the United States, Britain and France, in 1858. What's more, the Beijing Treaty (1860) between China and Britain allowed missionaries to buy or rent land and build churches anywhere in China. From then and until the 1950s, western Catholics played a great role in Chinese society. However, in People's Republic of China (PRC) the role of Catholics gradually weakened, and western religious influence was dispelled in the communist country. Today, China still lacks a normal relationship with the Vatican, whilst it has its own official catholic system.

\section{A Brief History of European Humanitarian Actions in China}

\subsection{First step : Go With the Empire: Missionary Involvement and Church Charity}

Christian charity (especially Catholic) was the first European approach to access the Chinese humanitarian arena. Preaching lied on top of the missionary agenda, and their relief actions were often regarded as subordinate and supporting instruments of proselytism. From the 16th to the 18th century, more than 800 missionaries came to China. For this reason, Sino-European communication of that time might be called the "Missionary Era ${ }^{18 "}$. In this era, missionary staffs took the responsibility of being the prime humanitarian technician: churches acted as humanitarian agencies, and catholic communities as humanitarian vectors.

Matteo Ricci was the first occidental person who conducted humanitarian relief in China. In 1583, Michele Ruggieri and himself built their first church in Southern China, and they lead a first relief attempt in 1586 - they provided a shelter for the victims of a flood in Zhaoqing. When Ricci moved to Beijing, capital city of the Ming Dynasty, he also assisted the governments to deliver relief to the flood victims in $1604^{19}$.

\footnotetext{
18 Ren, Dayuan, (2005) "The Influence and Contributions of Chinese Scholars on Huayi Xuezhi”, Beijing Forum: Academic Atmosphere and Traditions, Fu Jen Catholic University , September 11, 2005, pp. 39-44.

${ }_{19}$ National Library of China, Introduction of Matteo Ricci, Dataset of Foreign Sinologists, National Library of China.
} 
A second intervention by missionaries happened in 1634, when a serious famine hit Shanxi. Alfonso Vagnoni tried his best to help affected people and even built an orphan asylum that was financed by other missionaries and local Christians ${ }^{20}$. Compared with charity action provided by Matteo Ricci, Father Vagnoni provided a larger-scale and more organized relief.

Juan Adam Shall von Bell and Ferdinand Verbiest are two other well-known figures of Sino-European communication. Also missionaries, they were appointed to official positions in the Qing Dynasty, and had a close relationship with the emperors. Their advanced knowledge of astronomy and earthquake dynamics lead emperor Kangxi to revise Chinese calendars and seismic knowledge. In addition, Ferdinand Verbiest also provided minor relief in Inner Mongolia ${ }^{21}$.

A much more significant humanitarian action organized by Europeans with official appointments happened during the reign of the emperor Kangxi. Joachim Bouvet, Petrus Jartoux, Dominique Parennin and Jose Suarez started their humanitarian action in Beijing after a serious flood and a subsequent famine in Shandong. Their official appointment by the emperor Kangxi reflected the emperor's trust of foreign missionaries. The missionaries designed a procedure of relief signal and delivery address. With public money, they efficiently delivered food for the victims and provided sanitation services. According to Jartoux himself, this efficiency even made Chinese officials a little jealous. Eventually, this action lasted for 4 months and delivered food for more than one thousand victims ${ }^{22}$.

Timothy Richard was an epoch-making figure regarding Chinese humanitarian actions: he led a large scale relief action with John Nevius during a drought-famine-plague disaster in nine provinces of North China, especially in Shanxi. This drought lasted more than 3 years and led to a serious famine which was named "Dingwu Qibuang" where "Dingwu" stands for years 1877-1878, "Q $i$ " for unusual, surprising, incredible and serious, and "Huang" for a combination of many natural as well as human-made disasters. Almost 200 million people were affected, and 13 million died; a third of the population of the Shanxi Province lost their lives. The collapsing Qing government was unable to organize help because of fragile governmental capacity and internal and external threats. In order to deal with the catastrophe, they therefore had to ask for foreign assistance, namely to the Catholics. This relief was the first one to be fully "organized and

\footnotetext{
${ }^{20}$ Pfister, Louis, (1997) Notices biographiques et bibliographiques sur les Jésuites de l'ancienne mission de Chine, 1552-1773, translated by Mei Sehgnjun, Shanghai: Catholic Shanghai.

${ }^{21} \mathrm{Li}$, Yuwei, Catholic Kingdom and Anti-Catholic Movement, Xinhua News Agency, available at: http://www.nmg.xinhuanet.com/bnfynmg/bnbs/zzp/zz2.htm.

22 Jartoux, Petrus, (2008) "Conflict between Bouvet and Qing Prince", in Bouvet, Joachim, etc., Emperor Kangxi: A Perspective of Elder Foreigners, Beijing: People Daily Press.
} 
planned" by foreign missionaries in China. Not only did Richard advise the Qing government to displace people, and to provide food in exchange for work (Yigong Daizhen), he also called for money collection in Britain. The "London Major Disaster Relief Foundation" was born, and provided a significant amount of money to Chinese victims.

It appears from this short overview that social welfare and charity events directed by Christians usually focused on three aspects: medical service, children and elderly charity, and relief service. These three aspects are interrelated and provided technical conditions and experiences for further Chinese-lead humanitarian actions. By 1937, we count for example 70 hospitals - 5000 beds - built by French Catholic organizations. Meanwhile, Christian organizations from Britain and the United States had built 300 hospitals with 21,000 sickbeds. These European medical facilities promoted the development of medical technology in China and increased Chinese public health awareness ${ }^{23}$. Besides, it also appears that marginalized groups like children, orphans and elders were the target groups of Catholic organizations. In 1930, China was home to 306 orphan asylums with 74,752 orphans or abandoned children, and 232 welfare homes for the elder ${ }^{24}$.

\subsection{Second step: Humanitarian System Modernization: Attractivity, Organizations \& Socialization}

The birth in 1863 of the "International Committee for the Relief of Wounded Combatants" - that is, the Red Cross - symbolizes the emergence of modern humanitarianism. The first Geneva Convention introduced humanitarian action in law. In China, the attraction of the Red Cross was triggered during the Sino-Japanese War of the 1890s. More than two decades after the birth of the Red Cross Society, China started to acknowledge this organization. À series of articles about the Red Cross were published in papers like the Shen Newspaper (1898-1899) and the Takungpao Newspaper (which existed from 1872 to 1949). These articles mainly focused on the nature of humanitarian thought that drove the Red Cross Society, its aims, missions and functions. These articles attracted public attention and raised awareness. Almost at the same time, some Chinese people attempted to introduce new relief technologies like medical services, and to ask Qing officials to organize Red Cross committees in China. Sun Yat-sen, who later became the famous revolutionary leader, once translated a medical relief book of the Red Cross into Chinese, and Sun Gan, a Chinese businessman established in Japan

${ }^{23}$ Chen, Jianming, (2007) "Brief Discussion of the Conflict and Adaptation between Christian and Chinese Society", Religious Studies, No. 4, 2007.

${ }^{24}$ Chen, Jianming, (2007) "Brief Discussion of the Conflict and Adaptation between Christian and Chinese Society". 
who also had a position in the Japanese Red Cross, asked in 1897 to bring the organization in China.

The onset of the Russo-Japanese War in Northeast China in 1904 saw a lot of Chinese refugees and victims lose their homes. In this context, the first Chinese Red Cross organization - the International Red Cross Society of Shanghai - was established, with joint efforts of Britain, France, Germany and the United States ${ }^{25}$. This event constitutes the origin of modern humanitarian aid system in China.

In addition to the Red Cross Society of China, other important relief organizations were established with both Chinese traditional characters and Western features. On January 26, 1878, the China Disaster Relief Foundation was established in Shanghai by Christian missionaries, diplomats and businessmen, mainly to engage in money collection and food delivery. European humanitarian approaches were officially recognized and accepted by the Chinese. Missionary and church involvement into Chinese disaster relief was common place.

Subsequently, the westernization of Chinese humanitarian activities continued. After the 1931 flood relief in China, some people who participated in the relief activities thought it was necessary to create a permanent organization aimed at dealing with future disasters. China International Famine Relief Commission (CIFRC) was born and played a great role during the first half of the 20th century. The CIFRC presented itself as a relief organization "with complete disaster response mechanism", as the "first scientific and professional" non-profit charity organization. It functioned until the occupation of Shanghai by the Japanese army, when it integrated the Red Cross of Shanghai ${ }^{26}$.

\subsection{Third step: European clash: European Elements in Collision with other European Elements}

Something interesting took place when China went past the Second World War. The Chinese Communist Party (CCP), the ruling party in China, takes its roots in Marxism. Confronted to this revolutionary approach and class analysis perspective, mainstream European humanitarian approaches were abandoned, as they revealed "bourgeois humanitarianism", functioned as "a tool used by the bourgeoisie", and covered up "capi-

${ }^{25}$ Chi, Zihua, (2004) "The Origin of the Red Cross and Its Spreading in Modern ChinaCommemorate the 100th Anniversary of the Red Cross Society of China", Journal of Hefei University (Social Sciences), Vol. 21, No. 1, 2004.

26 Huang, Wen De, (2004) Non-Governmental Organizations and International Cooperation in China: A Study on China International Famine Relief Commission, Showwe Technology Limited, pp.315-317. 
talism's merciless exploitation and oppression, to cover up class contradictions, and to deceive the proletariat and the working people ${ }^{27}$."

Within this kind of political atmosphere, all elements related to Western countries were destroyed or repudiated, during the Cultural Revolution (1966-1976) and other less spectacular moments. However, this was not a consequence of Chinese traditions, which had to confront the same tragedy. The humanitarian ethos had been eliminated by another European system of thought: the radical left. During the 1959-1961 famine, as well during the Tangshan Earthquake of 1976, the government even refused all humanitarian assistance ${ }^{28}$. At the same time, China was providing aid to its third world allies in Africa and socialist friends such as Albania and Vietnam, in spite of its own economic meltdown.

\subsection{Fourth step: Back to Track?}

With the development of Chinese Open Policy, China engaged in a new pace towards global economical and political spheres. Although the debate on Marxist humanism was still hot, Chinese attitudes to international humanitarian relief changed step by step as the country got rid of isolation policies.

When a serious disaster combining drought in the North and flood in the South (with a subsequent famine) hit China in 1980, the government realized the necessity of urgent international humanitarian action. At the time, the Times reported: "This is the first time that Chinese government accepts international assistance [...] begins to deal with disasters with the hand of assistance". However, the humanitarian assistance was restricted to a single province and limited to specific aid materials, which indicates the persistence of a conservative attitude from the Chinese government. The first time that China actively asked for international aid of various types dates back to May 1987, when a forest fire burnt during almost a month, killing more than 200 people and forcing 50,000 people out of their homes. For the 1991 flood in East China, Chinese government also asked the global community for aid "directly and in a larger scale ${ }^{29 "}$.

In the following years, China faced the SARS crisis, many earthquakes (especially those of May 12, 2008), and other natural disasters. To deal with each disaster, the Chi-

\footnotetext{
27 Cited from Hirono, Miwa, (2009) "China's Conception of Humanitarianism in Africa: Root of Anti-Western Discourse", in Kwabena Akurang-Parry, ed., China in Africa: A Moment of 'Second Imperialism' or Progressive Partnership, Edwin Mellen Press, (forthcoming).

${ }^{28}$ Zhan, Yijia, (2006) "Thirty Years After Tangshan Earthquake: The Process of Chinese Acceptance of Humanitarian Assistance", World Knowledge, Vol. 14, 2006; Wang, Shuo and Zhang Xu, (2008) “The Process of PRC Confronting International Relief”, World Newspaper, May 27, 2008. ${ }^{29}$ Zhan, Yijia, (2006) "Thirty Years After Tangshan Earthquake: The Process of Chinese Acceptance of Humanitarian Assistance".
} 
nese government and the China Red Cross have actively required international assistance. On the other hand, China has also continued to deliver humanitarian aid to foreign disaster-affected countries, such as during the Indian Ocean Tsunami of $2004^{30}$

At present, the humanitarian system in China includes new actors like international and native local NGOs. Some famous relief NGOs like Oxfam, Actionaid, World Vision, etc. have established an office in China. Chinese officials tolerate this trend, but don't give it any legal framework. Some disaster-response NGOs have a functional relationship with relevant governmental departments. For example, Oxfam Hong Kong has been active within the Chinese humanitarian system, but has no legal existence. After the Wenchuan Earthquake, Oxfam Hong Kong has nonetheless built an official cooperation with the State Council Leading Office of Poverty Alleviation and with the Development and International Poverty Reduction Center in China. Oxfam is therefore allowed to participate in reconstruction projects in earthquake-hit regions.

\section{ECHO \& China: "From Monologue to Dialogue to Collaboration" ${ }^{31}$}

A few decades ago, the European Community began to participate in worldwide humanitarian affairs as a loosely unitary actor. In April 1992, an official organization, namely the European Community Humanitarian Aid Office (ECHO), was established within EU structures to handle humanitarian issues. ECHO usually functions well and promotes the three pillars of the EU. In spite of the hot debates and political divergences on common foreign relations among EU members, their attitudes to humanitarian affairs are usually coherent. ECHO is regarded as a robust tool to promote European values and to enforce EU "soft power" globally. As a single entity, ECHO represented about $16 \%$ of global humanitarian aid from 1995 to 2007 on average, and even accounted for about $32 \%$ in 1996. As the world's most important humanitarian donor, ECHO and EU members states usually contributes to about $30 \%$ of the global humanitarian donor share, with a peak to more than $52 \%$ in $1998^{32}$. During the Tsunami, Europe contributed to some $48 \%$ of the overall financial aid ${ }^{33}$.

\footnotetext{
30 Mao, Weizhun \& Que Tianshu, (2005) "Disaster Diplomacy: A New Diplomatic Approach The Apocalypse Of the Indian Ocean Earthquake and Tsunami", World Economics and Politics, Vol. 6, 2005.

31 The title is borrowed from Geoffrey Cowan and Amelia Arsenault (2008), "Moving from Monologue to Dialogue to Collaboration: The Three Layers of Public Diplomacy", The ANNALS of the American Academy of Political and Social Science, Vol. 616, No. 1, pp. 10-30.

32 Calculated according to the data from in ECHO (2008), Financial Report 2008, Directorate General for Humanitarian Aid (ECHO), European Commission, p. 20.

33 OCHA (2005), Natural Disasters Highlights, No. 2, August 2005, Geneva.
} 
Regarding Sino-European humanitarian activities, ECHO has been deeply involved into Chinese disaster responses and humanitarian activities since its birth. During the last 20 years or so, ECHO has gained reconnaissance among more and more Chinese people, including scholars, government officials, NGO professionals, and the public in general $^{34}$. From 1998 to 2008, ECHO has injected 21,73 million euros in China, for almost all the serious natural disasters, and especially for the floods in 1998 and the Wenquan Earthquake in $2008^{35}$.

ECHO has exerted its influence in China through at least three ways. The advocacy of European values, the design of humanitarian standards, and the development of a regional disaster-response model for China and its neighboring countries. Let us consider these elements one by one.

First, ECHO undertakes the task to advocate EU values, which place the individual human being at the centre of attention. ECHO has been cooperating with various international humanitarian agencies (like OCHA) and relevant Chinese official agencies, but mainly as a donor: ECHO doesn't usually intervene directly in China ${ }^{36}$. As a pioneer on humanitarian relief and human values, the EU may have positively increased awareness of Chinese humanitarians and even of the affected people of disaster-hit areas, on general human values like human security, rights to survival, and other human rights and liberties. Principles such as humanity, neutrality, impartiality and independence are also put forward. ECHO approaches, which are people-oriented and needbased, have spread among related agencies in China as well.

Second, ECHO is a major humanitarian standard designer in global humanitarian affairs. This role has impacted Chinese humanitarian reliefs in various disaster-response activities. ECHO has been emphasizing issues like the speed and quality of humanitarian aid delivery. ECHO indeed calls for agencies to follow "a set of internationally recognized standards and principles" like the Sphere Project ${ }^{37}$. In May 2008, the many international teams and NGOs which took part in the humanitarian operations after the Wenchuan Earthquake - including official technical teams from European countries, Europe-based relief NGOs (Oxfam, etc.) and ECHO financially supported agencies applied EU standards in their activities. This dynamic has lead Chinese professionals and the affected people to upgrade their operational standards.

34 See http://www.mfb.sh.cn/mfbinfoplat/platformdata/infoplat/pub/shmf_104/docs/200807 /d_59340.html.

35 Calculated according to the data from ECHO, ECHO Annual Review (1998-2008), ECHO, EU.

${ }^{36}$ ECHO (2008), Annual Report on Humanitarian Aid, 2008, ECHO, EU, p. 87.

${ }^{37} \mathrm{EU}$ (2007), The European Consensus on Humanitarian Aid, Joint Statement by the Council and the Representatives of the Governments of the Member States meeting within the Council, the European Parliament and the European Commission, 18 December 2007. 
Third, ECHO has also shaped a regional institutional model set up to deal with humanitarian emergencies in China and its neighboring countries, echoing in this the wellknown boom in regional integrations. This successful experience encouraged some Chinese scholars in think-tanks to call for an international cooperative disaster response system $^{38}$. To this regard, ECHO's focus on prevention and readiness has been emphasized by Chinese scholars as well ${ }^{39}$. With its remarkable humanitarian power in the world, ECHO provides a model for China to consider this kind of approach.

More recently, China started to cooperate with ECHO on some humanitarian issues at the global scale, such as the tsunami, which tends to prove the birth of a true interaction. In addition to relief cooperation after natural disasters, China also began to cooperate with the EU on some human-made emergencies, especially wars. During the conflict in Darfur, China and the EU somehow collaborated to enforce political dialogue, peacekeeping, conflict resolution, and refugees aid, regardless of their potential differences.

However, ECHO is still in collision with China on several aspects, especially on the relationship between human rights and sovereignty. These divergences are not only ideological, but also engage political considerations from a realpolitik perspective.

To sum up, the relationship between China and ECHO seems to be an epitome of the long history of Sino-European humanitarian interactions. As a traditional and powerful humanitarian actor, ECHO demonstrated an unsymmetrical interaction with China, because of its humanitarian expertise and its focus on values. After the "monologue" of the initial phase, China engaged in a "dialogue" with ECHO: the country reexamined its humanitarian practices, re-evaluated its response systems, and tried to deal with humanitarian assistance on an equal basis. Today, China and ECHO enter a "collaborative" phase, and work together on various humanitarian issues. This "Monologue-Dialogue-Collaboration" process between China and ECHO has been marked by clashes and disjunctions.

\section{Concluding Remarks}

European culture has always been a major provider of renewal in Chinese humanitarian practices. Chinese humanitarian aid system has undergone a long-term mutation that owes its logic to the successive arrivals of European cultural elements. We examined these steps in the second part of our paper. It appears that Europe and China have

\footnotetext{
38 Conference on Asia-Europe Disaster Response Capacities Building, 29 May 2009, Chengdu, China, available at: http://www.chengdu.gov.cn/govAffairInfo/detail.jsp?id=259191.

39 http://www.mfb.sh.cn/mfbinfoplat/platformdata/infoplat/pub/shmf_104/docs/200807 /d_59340.html.
} 
played various roles in this process, such as teacher and student, competitors, or finally collaborators.

As the pillar of global humanitarian actions since the $19^{\text {th }}$ century, Europe has directly and indirectly influenced Chinese humanitarian approaches on several aspects. First, Europe established a model of humanitarianism for China and other countries. In a country characterized by a "strong state versus a weak society", European intervention greatly improved the impetus for a quality disaster relief, and enhanced the mobilization of other agencies. Second, Europe provided humanitarian experts, advanced humanitarian technologies and relief experiences. Those have been shared, and contributed to the development of a modern humanitarian system in China. Third, Europe has implemented a lot of disaster response and relief laws which have become legal models for other countries, including China. Fourth, European involvement has reduced the suffering of millions of Chinese who were threatened by disasters. But besides these direct influences, it is clear that European cultures also contributed to raise awareness and reflection about Chinese traditions, and hence stimulated the growth of Chinese civil society.

More generally, the bilateral interaction on values between Europe and China is characterized by an atypical dialogue made of dramatic collisions, and disjunctive inheritance. This dialogue between two cultural centers has indeed been an atypical process because of the arrogance and superiority of both civilizations. Matteo Ricci attempted a discussion between Catholicism and Confucianism, but the final result failed to prove constructive. The "Ritual Controversy", engaged when George McCartney came to visit the emperor Qianlong, made the Europeans realize the fragility of China and the impossibility of a peaceful dialogue ${ }^{40}$. Warships and cannons therefore knocked on the door of China, and forced the discussion. Similarly, the development of Chinese humanitarian system has been dominated by European discourses during the whole process. This should lead us to say that careful humanitarian actions should always be grounded in the local culture "to have the necessary resource or technology", and that Western models of aid are not always "transferable ${ }^{41}$ ".

A lot of dramatic clashes occurred when the two civilizations met. The interplay between politics and faith intensified the tensions. When humanitarian relief and charity were bonded to Christian preaching, and when these Christian activities were confronting imperial interests and expressing colonizing behaviors, how could a disasteraffected country and its population accept the humanitarian actions and its principles?

40 Peyrefitte, Alain, (1993) The Immobile Empire: The First Great Collision of the East and West, translated by Wang Guoqing, etc., Beijing: SDX Joint Publishing Company.

${ }^{41}$ Neal, Joan, (2007) "Transformation from Relief to a Justice and Solidarity Focus", in Cahill, Kevin, (2007) The Pulse Of Humanitarian Assistance, Fordham University Press. 
In China, anti-Catholic movements therefore emerged at the end of the $19^{\text {th }}$ century, triggering social instability and even armed conflicts. Truly, the tension between humanitarian Euro-centrism and localization of aid shaped in China a series of dramatic episodes. The cultural collision between Chinese and European perspectives on humanitarian actions still frequently occurs ${ }^{42}$.

In the development of a modern humanitarian system in China, the inheritance of humanitarianism has often been disrupted, because of two phenomena. On the one hand, China hasn't found an integrated framework able to intermingle European elements with Chinese traditions, which indicates that the two traditions are still disjunctive. On the other hand, Europeans were always considered as a threat. This kind of perception encouraged Chinese officials to reject all that was labeled "Made in Europe".

42 Dgerton-Tarpley, Kathryn, (2007) "Famine and Ideology in Late-Qing China: Contending Interpretations of Famine Causation and Prevention during the 'Incredible Famine' of 1876-1879", in Li, Wenhai and Xia Mingfang, Disaster and Famine in Qing Dynasty and Chinese Society, Beijing: SDX Joint Publishing Company. 